\title{
Serological tests for syphilis in healthy rabbits
}

\author{
JOHN W. CLARK, JR. \\ Venereal Disease Research Laboratory, Venereal Disease Branch, State and Community Services Division, \\ National Communicable Disease Center, Health Services and Mental Health Administration, Public Health Service, \\ U.S. Department of Health, Education, and Welfare, Atlanta, Georgia, 30333, U.S.A.
}

Serological tests for syphilis (STS), as well as being important aids in the diagnosis of syphilis in man, are important in the study of experimental syphilis in animals. Rabbits not infected with Treponema pallidum sometimes show reactivity in one or another of the several available serological tests for the disease and, with the exception of the enzootic rabbit-spirochaetosis caused by Treponema cuniculi (Kolmer and Casselman, 1913), the reasons for such reactivity in rabbits have not been determined.

Serological testing is one of the more objective means of following the course of experimental animal syphilis, and the rabbit is the most frequently used experimental model in this disease. The reactivity pattern in certain tests is defined here for rabbits that, so far as can be determined, are not infected with treponemes.

\section{Material and methods}

Rabbits were acquired from commercial breeders and from the Lawrenceville Animal Breeding Facility of the National Communicable Disease Center (NCDC). All were examined upon arrival, and darkfield studies were made of exudates from any lesion, abrasion, or erythematous area, special attention being given to those near the body orifices. A serum specimen was collected from each animal. Many rabbits were re-examined periodically, including a darkfield examination.

The animals were housed in individual cages under standard conditions, and 36 were bled each week for 12 weeks. Serum specimens were collected from others at minimum intervals of 1 month, for 1 to more than 12 months.

Sera were tested by one or more of the following procedures: the fluorescent treponemal antibody-1:5 (FTA-1 : 5); the fluorescent treponemal antibodyabsorption (FTA-ABS) test as modified by Mothershed, Yobs, and Clark (1967); the Venereal Disease Research Laboratory (VDRL) slide test; the one-fifth volume Kolmer with Reiter protein antigen (KRP); and the Treponema pallidum immobilization (TPI) test (U.S.

Received for publication September 5, 1969.

Trade names are used for identification only and do not represent an endorsement by the Public Health Service or the U.S. Department of Health, Education,; and Welfare.
Public Health Service, 1964). These tests were performed by or under the supervision of the Standardization and Consultation Services Unit, or by the Treponematoses and Allied Diseases Research Unit of the Venereal Disease Research Laboratory.

Attempts were made to transfer STS reactivity to nonreactive animals. One method was to inject into nonreactive rabbits popliteal and inguinal node material and testicular tissues of rabbits with FTA-ABS reactivity and/or VDRL reactivity at 4 or more dilutions, as well as of those with sustained lower levels of reactivity. Another method was to cage reactive rabbits with non-reactive members of the opposite sex for extended periods.

To determine the effect of STS reactivity on susceptibility to syphilis infection, rabbits with at least a 6-month history of such reactivity were inoculated with graduated doses of T.pallidum.

In all, the study involved 5,363 adult male rabbits: 4,324 New Zealand Whites from the breeding colony of the NCDC; 1,039 rabbits of this and comparable breeds, and mongrels from commercial sources. The numbers of animals tested by the different procedures were:

\begin{tabular}{|c|c|}
\hline Test & No. of rabbits \\
\hline $\begin{array}{l}\text { VDRL slide } \\
\text { FTA } 1: 5 \\
\text { FTA-ABS } \\
\text { TPI } \\
\text { KRP }\end{array}$ & $\begin{array}{r}5,363 \\
2,987 \\
3,019 \\
2,394 \\
632\end{array}$ \\
\hline
\end{tabular}

Two of 2,394 rabbits tested reacted to the TPI test; one was overtly reactive, the other exhibited borderline reactivity. These two commercially-produced rabbits had infectious (animal transfer) T. cuniculi and were excluded from the study.

\section{Results}

The results with the remaining four procedures are shown in Table I (overleaf). Commercially acquired rabbits included a higher proportion of reactors than did those produced in the laboratory colony.

As noted earlier, all rabbits were not subjected to each of the tests. However, sera from 632 rabbits were tested by all five procedures. None was reactive with the TPI test, but 481 , were at least weakly reactive with one or more of the other tests. Eight of 
TABLE I Results of serological tests for syphilis in apparently healthy adult male domestic rabbits

\begin{tabular}{|c|c|c|c|c|c|c|c|c|c|c|c|c|}
\hline \multirow{3}{*}{$\begin{array}{l}\text { Rabbit } \\
\text { source }\end{array}$} & \multicolumn{3}{|c|}{$F T A-1: 5$} & \multicolumn{3}{|c|}{$F T A-A B S$} & \multicolumn{3}{|c|}{ VDRL slide } & \multicolumn{3}{|l|}{$K R P$} \\
\hline & \multirow{2}{*}{$\begin{array}{l}\text { No. of } \\
\text { rabbits } \\
\text { tested }\end{array}$} & \multicolumn{2}{|c|}{$\begin{array}{l}\text { Percentage } \\
\text { reactive }\end{array}$} & \multirow{2}{*}{$\begin{array}{l}\text { No. of } \\
\text { rabbits } \\
\text { tested }\end{array}$} & \multicolumn{2}{|c|}{$\begin{array}{l}\text { Percentage } \\
\text { reactive }\end{array}$} & \multirow{2}{*}{$\begin{array}{l}\text { No. of } \\
\text { rabbits } \\
\text { tested }\end{array}$} & \multicolumn{2}{|c|}{$\begin{array}{l}\text { Percentage } \\
\text { reactive }\end{array}$} & \multirow{2}{*}{$\begin{array}{l}\text { No. of } \\
\text { rabbits } \\
\text { tested }\end{array}$} & \multicolumn{2}{|c|}{$\begin{array}{l}\text { Percentage } \\
\text { reactive }\end{array}$} \\
\hline & & $\begin{array}{l}\text { Less } \\
\text { than } \\
1+\end{array}$ & $\begin{array}{l}1+ \\
\text { and } \\
\text { greater }\end{array}$ & & $\begin{array}{l}\text { Less } \\
\text { than } \\
1+\end{array}$ & $\begin{array}{l}1+ \\
\text { and } \\
\text { greater }\end{array}$ & & $\begin{array}{l}\text { Slightly } \\
\text { reactive }\end{array}$ & $\begin{array}{l}\text { R.1 } \\
\text { and } \\
\text { greater }\end{array}$ & & $\begin{array}{l}\text { Less } \\
\text { than } \\
1+\end{array}$ & $\begin{array}{l}1+ \\
\text { and } \\
\text { greater }\end{array}$ \\
\hline NCDC & 2,504 & $18 \cdot 5$ & $15 \cdot 9$ & 2,533 & $2 \cdot 8$ & $1 \cdot 3$ & 4,324 & $8 \cdot 8$ & 4.9 & 477 & $21 \cdot 1$ & $20 \cdot 6$ \\
\hline Commercial & 483 & $24 \cdot 8$ & $16 \cdot 8$ & 486 & $5 \cdot 8$ & $1 \cdot 2$ & 1,039 & $16 \cdot 2$ & $14 \cdot 8$ & 155 & $20 \cdot 0$ & $40 \cdot 7$ \\
\hline Total & 2,987 & $19 \cdot 6$ & $16 \cdot 0$ & 3,019 & $3 \cdot 4$ & 1.3 & 5,363 & $10 \cdot 0$ & 6.9 & 632 & $20 \cdot 8$ & 25.5 \\
\hline
\end{tabular}

TABLE I I Correlation of reactivity with four STS tests. Results with other STS procedures in rabbits reactive with any one test

\begin{tabular}{|c|c|c|c|c|c|c|c|c|}
\hline \multirow{2}{*}{\multicolumn{2}{|c|}{$\begin{array}{l}\text { Rabbits reactive } \\
\text { with } \\
\text { one test }\end{array}$}} & \multirow{3}{*}{$\begin{array}{l}\text { Percentage } \\
\text { non-reactive } \\
\text { with } \\
\text { all other tests }\end{array}$} & \multirow{3}{*}{$\begin{array}{l}\text { Percentage } \\
\text { reactive } \\
\text { with } \\
\text { all other tests }\end{array}$} & \multicolumn{5}{|c|}{ Percentage reactive with given tests } \\
\hline & & & & \multirow[b]{2}{*}{$F T A-1: 5$} & \multirow[b]{2}{*}{$F T A-A B S$} & \multirow[b]{2}{*}{$V D R L$ slide } & \multirow[b]{2}{*}{$K R P$} & \multirow{2}{*}{$\begin{array}{l}V D R L \text { slide } \\
\text { and } \\
F T A-A B S\end{array}$} \\
\hline Test & No. & & & & & & & \\
\hline FTA-1: 5 & 961 & 63 & 3 & - & 12 & 18 & 45 & 3 \\
\hline FTA-ABS & 126 & 1 & $20^{2}$ & 86 & 一 & 25 & $60^{1}$ & 25 \\
\hline VDRL slide & 447 & 59 & $7^{1}$ & 36 & 7 & 一 & $30^{1}$ & 7 \\
\hline $\mathbf{K} \mathbf{R} \mathbf{P}$ & 293 & 44 & 3 & 44 & 8 & 23 & - & 3 \\
\hline
\end{tabular}

${ }^{1} \mathrm{KRP}$ test not performed on all sera. The number of rabbits in the 'Reactive' column was tested in all other combinations listed.

the 632 showed reactivity to each of the four remaining procedures. Sera from 2,949 animals were tested by the FTA-1 : 5, the FTA-ABS, and the VDRL slide tests; 25 showed reactivity with all three tests, and some reactivity was detected in 1,343 by at least one test, with 558 showing significant reactivity with levels at or above $1+$ or 1 dilution. Results of battery serological testing for animals reactive to any one test are presented in Table II.

\section{STS reactivity of rabbits on follow-up examination}

Sera of 36 rabbits were examined by the VDRL slide test each week for 14 weeks. Seven rabbits reacted at one dilution in one or more of the 14 weeks, three of these at the initial bleeding. One animal was consistently reactive. Of the 84 specimens from the remaining six rabbits which showed intermittent reactivity at one or more dilutions, 34 ( 40.5 per cent.) reacted at least minimally. 29 rabbits were nonreactive in each of the 14 weeks.

Two specimens were collected from each of 1,413 rabbits at intervals of 4 to 8 weeks and examined by three or four test procedures. The results are shown in the Figure (opposite). Rabbits showing borderline reactivity in the first specimen produced a range of equivocal results at the second bleeding. These results were not tabulated.

Certain of these rabbits were tested at intervals of 4 to 8 weeks for 2 to 18 months or longer. The numbers of the original group still available for further study at the various periods and the proportions with consistent results (minimal reactors considered non-reactive) are given in Table III (opposite).

Not all of these were randomly selected. Some were known to have been reactive with one or more tests; some completely non-reactive at the first and/or second examination. As an example of the variability observed, Table IV (overleaf) presents data for sixteen individual animals examined eight or more times with inconsistent results.

No other evidence of treponemal infection was obtained.

We have demonstrated $T$. cuniculi in asymptomatic rabbits by moistening the genital mucosa with 0.85 per cent. $\mathrm{NaCl}$ and examining the collected fluid by darkfield examination (Clark, in preparation). Eleven rabbits VDRL-reactive at from 1 to 16 dilutions over 6 to 18 months-four of the nine tested being FTAABS reactive-were examined repeatedly by this method. No treponemes were seen in the rabbits in this study. 

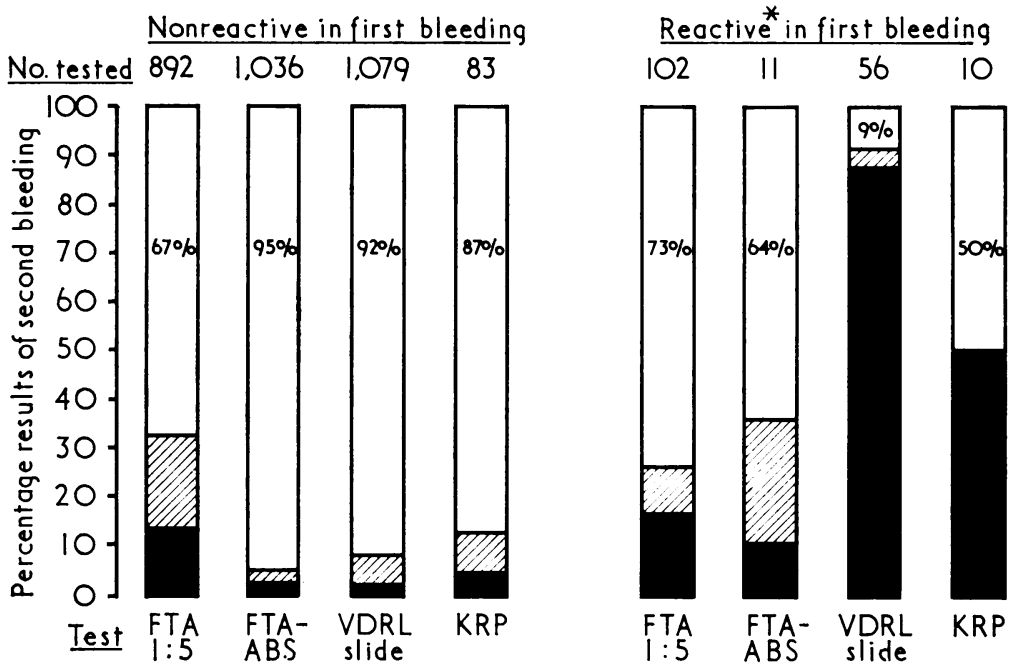

Nonreoctive

Slightly reactive

Reoctive

FIGURE Results of serological tests for syphilis in apparently healthy rabbits re-examined after 4 to 8 weeks.

$\star$ Overtly $\left(1^{+}\right.$, Reactive at 1 dilution, or More) reactive. Results of second specimen from rabbits with slight reactions initially are not tabulated.

TABLE I I I Reproducibility in the same healthy rabbits of results with STS tests repeated from twice to ten times at intervals of 4 or more weeks

\begin{tabular}{|c|c|c|c|c|c|c|c|c|}
\hline \multirow{3}{*}{$\begin{array}{l}\text { Number of } \\
\text { specimens } \\
\text { from each } \\
\text { rabbit }\end{array}$} & \multicolumn{8}{|c|}{ Serological tests for syphilis } \\
\hline & \multicolumn{2}{|c|}{$F T A-1: 5$} & \multicolumn{2}{|c|}{$F T A-A B S$} & \multicolumn{2}{|l|}{$V D R L$} & \multicolumn{2}{|c|}{ All three tests } \\
\hline & $\begin{array}{l}\text { No. of } \\
\text { rabbits }\end{array}$ & $\begin{array}{l}\text { Percentage } \\
\text { agreement }^{1}\end{array}$ & $\begin{array}{l}\text { No. of } \\
\text { rabbits }\end{array}$ & $\begin{array}{l}\text { Percentage } \\
\text { agreement }^{1}\end{array}$ & $\begin{array}{l}\text { No. of } \\
\text { rabbits }\end{array}$ & $\begin{array}{l}\text { Percentage } \\
\text { agreement }^{1}\end{array}$ & $\begin{array}{l}\text { No. of } \\
\text { rabbits }\end{array}$ & $\begin{array}{l}\text { Percentage } \\
\text { agreement }^{1}\end{array}$ \\
\hline $\begin{array}{r}2 \\
3 \\
4 \\
5 \\
6 \\
7 \\
8 \\
9 \\
10\end{array}$ & $\begin{array}{r}1,413 \\
217 \\
65 \\
49 \\
47 \\
33 \\
16 \\
11 \\
4\end{array}$ & $\begin{array}{l}82 \\
37 \\
37 \\
33 \\
32 \\
27 \\
12 \\
17 \\
25\end{array}$ & $\begin{array}{r}1,413 \\
217 \\
65 \\
49 \\
47 \\
33 \\
16 \\
11 \\
4\end{array}$ & $\begin{array}{l}97 \\
83 \\
70 \\
71 \\
66 \\
64 \\
44 \\
45 \\
50\end{array}$ & $\begin{array}{r}1,413 \\
295 \\
82 \\
66 \\
64 \\
50 \\
16 \\
11 \\
4\end{array}$ & $\begin{array}{r}99 \\
78 \\
77 \\
72 \\
72 \\
64 \\
25 \\
17 \\
0\end{array}$ & $\begin{array}{r}1,413 \\
217 \\
65 \\
49 \\
47 \\
33 \\
16 \\
11 \\
4\end{array}$ & $\begin{array}{r}81 \\
31 \\
29 \\
22 \\
21 \\
18 \\
0 \\
0 \\
0\end{array}$ \\
\hline
\end{tabular}

${ }^{1}$ Agreement with all previous examinations

\section{Infectivity tests}

Lymph node and/or testicular tissue extracts from each of nine of the eleven rabbits described above were inoculated into the testicles of two nonreactive rabbits. These animals had been reactive with the VDRL slide quantitative test at from 1 to 16 dilutions for 6 to 18 months. In the FTA-ABS test, two had been repeatedly reactive and two intermittently so. Popliteal node material from six reactors was transferred to twelve rabbits; both popliteal node material and testicular tissue from two reactors into four rabbits; and the last two tissues, together with that of the inguinal nodes from one reactor, into two rabbits. The recipients showed no indication of treponematosis and remained non-reactive with the VDRL slide test during an observation period of 6 to 12 months.
Cuniculosis is readily spread by sexual contact (Smith and Pesetsky, 1967; Clark, in preparation). Four male rabbits showing repeated reactivity in the FTA $1: 5$, FTA-ABS, and VDRL slide test were each caged for 3 months with a non-reactive female. The four females remained clinically and serologically normal after 12 months, as did the recipients of their node tissues.

\section{Tests for resistance to experimental infections}

To investigate possible resistance to the inoculation of small numbers of $T$. pallidum, as few as two treponemes were injected into each of five rabbits with 6-month histories of reactive results in the VDRL slide test. Two treponemes produced darkfield-positive chancres in two of the five reactive 
TABLE IV STS results in sixteen healthy rabbits tested eight times at intervals of 1 to 2 months for 12 to eighteen mont

\begin{tabular}{|c|c|c|c|c|c|c|c|c|c|c|c|c|c|c|c|c|}
\hline \multirow{3}{*}{ Rabbit No. } & \multicolumn{16}{|c|}{ Test No. } \\
\hline & \multicolumn{4}{|l|}{1} & \multicolumn{4}{|l|}{2} & \multicolumn{4}{|l|}{3} & \multicolumn{4}{|l|}{4} \\
\hline & $\begin{array}{l}F T A- \\
1: 5\end{array}$ & $\begin{array}{l}F T A- \\
A B S\end{array}$ & $\begin{array}{l}V D R L \\
\text { slide }\end{array}$ & $T P I$ & $\begin{array}{l}F T A- \\
1: 5\end{array}$ & $\begin{array}{l}F T A- \\
A B S\end{array}$ & $\begin{array}{l}\text { VDRL } \\
\text { slide }\end{array}$ & $T P I$ & $\begin{array}{l}F T A- \\
1: 5\end{array}$ & $\begin{array}{l}F T A- \\
A B S\end{array}$ & $\begin{array}{l}\text { VDRL } \\
\text { slide }\end{array}$ & $T P I$ & $\begin{array}{l}F T A- \\
1: 5\end{array}$ & $\begin{array}{l}F T A- \\
A B S\end{array}$ & $\begin{array}{l}\text { VDRL } \\
\text { slide }\end{array}$ & 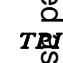 \\
\hline $\begin{array}{l}2440 \\
2489 \\
2525 \\
2531 \\
3270 \\
3534 \\
3542 \\
4040 \\
4176 \\
4182 \\
4210 \\
4233 \\
4480 \\
2672 \\
3673 \\
3532\end{array}$ & $\begin{array}{l}4+ \\
\text { WR } \\
\mathbf{N} \\
\mathbf{N} \\
\mathbf{N} \\
2+ \\
\text { WR } \\
\mathbf{N} \\
\mathbf{N} \\
\text { WR } \\
1+ \\
\mathbf{N} \\
\mathbf{N} \\
\mathbf{N} \\
\mathbf{N} \\
\mathbf{N}\end{array}$ & $\begin{array}{l}\mathbf{N} \\
\mathbf{N} \\
\mathbf{N} \\
\mathbf{N} \\
\mathbf{N} \\
\mathbf{1}+ \\
\mathbf{N} \\
\mathbf{N} \\
\mathbf{N} \\
\mathbf{N} \\
\mathbf{W R} \\
\mathbf{N} \\
\mathbf{N} \\
\mathbf{N} \\
\mathbf{N} \\
\mathbf{N}\end{array}$ & $\begin{array}{l}\text { WR } \\
R-2 \\
R-4 \\
R-8 \\
R-4 \\
R-4 \\
\text { N } \\
\text { N } \\
R-8 \\
R-4 \\
R-1 \\
R-2 \\
R-2 \\
N \\
N \\
R-2\end{array}$ & $\begin{array}{l}\mathbf{N} \\
\mathbf{N} \\
\mathbf{N} \\
= \\
= \\
= \\
= \\
= \\
= \\
= \\
=\end{array}$ & $\begin{array}{l}- \\
- \\
\bar{N} \\
4+ \\
\mathbf{N} \\
1+ \\
1+ \\
\text { WR } \\
2+ \\
4+ \\
\mathbf{N} \\
\mathbf{N} \\
\text { WR } \\
\mathbf{1 +}\end{array}$ & $\begin{array}{l}\text { 二 } \\
\text { 二 } \\
\mathbf{N} \\
4+ \\
\mathbf{N} \\
\mathbf{1}+ \\
\mathbf{N} \\
\mathbf{N} \\
\mathbf{N} \\
\mathbf{4 +} \\
\mathbf{N} \\
\mathbf{N} \\
\mathbf{N} \\
\mathbf{N}\end{array}$ & $\begin{array}{l}\text { WR } \\
\text { R-2 } \\
\text { R-1 } \\
R-8 \\
R-16 \\
R-2 \\
R-1 \\
N \\
R-4 \\
R-2 \\
R-1 \\
R-2 \\
R-1 \\
N \\
N \\
R-4\end{array}$ & $\begin{array}{l}\bar{Z} \\
N \\
\frac{N}{N} \\
\frac{\bar{N}}{N} \\
\frac{N}{Z} \\
=\end{array}$ & $\begin{array}{l}\text { WR } \\
\text { N } \\
\text { WR } \\
1+ \\
1+ \\
4+ \\
1+ \\
2+ \\
\text { N } \\
2+ \\
1+ \\
\text { WR } \\
\text { WR } \\
1+ \\
1+ \\
1+\end{array}$ & $\begin{array}{l}\mathbf{N} \\
\mathbf{N} \\
\mathbf{N} \\
\mathbf{N} \\
\mathbf{W R} \\
1+ \\
1+ \\
\mathbf{N} \\
\mathbf{N} \\
\text { WR } \\
\mathbf{N} \\
\mathbf{N} \\
\mathbf{W R} \\
1+ \\
1+ \\
1+\end{array}$ & $\begin{array}{l}\text { WR } \\
\text { R-1 } \\
\text { WR } \\
\text { R-1 } \\
\text { N } \\
\text { R-1 } \\
\text { R-1 } \\
\text { N } \\
\text { R-16 } \\
\text { R-1 } \\
\text { WR } \\
\text { R-1 } \\
\text { R-1 } \\
\text { N } \\
\text { N } \\
\text { R-2 }\end{array}$ & $\begin{array}{l}\mathbf{N} \\
\mathbf{N} \\
\mathbf{N} \\
\mathbf{N} \\
\mathbf{N} \\
\mathbf{N} \\
\mathbf{N} \\
\mathbf{N} \\
\mathbf{N} \\
\mathbf{N} \\
\mathbf{N} \\
\mathbf{N} \\
\mathbf{N} \\
\mathbf{N} \\
\mathbf{N}\end{array}$ & $\begin{array}{l}\overline{1+} \\
\overline{-} \\
\bar{N} \\
3+ \\
\mathbf{N} \\
\mathbf{N} \\
\text { WR } \\
3-4+ \\
\text { WR } \\
\text { WR } \\
\text { 1+ } \\
\text { WR } \\
\text { N } \\
\text { N }\end{array}$ & $\begin{array}{l}-\overline{W R} \\
\mathbf{N} \\
\mathbf{N} \\
\mathbf{N} \\
2- \\
\mathbf{N} \\
\mathbf{N} \\
\text { WR } \\
\text { WR } \\
\text { WR } \\
\text { WR } \\
\mathbf{N} \\
\mathbf{N} \\
\mathbf{N} \\
\mathbf{N}\end{array}$ & $\begin{array}{l}N \\
R-1 \\
\text { WR } \\
R-2 \\
R-1 \\
R-2 \\
R-2 \\
N \\
R-4 \\
R-2 \\
\text { WR } \\
R-1 \\
\text { WR } \\
N \\
N \\
R-2\end{array}$ & 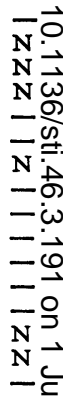 \\
\hline
\end{tabular}

$-\leq$ Not tested $\quad \mathrm{N}=$ Non-reactive $\quad$ WR $=$ Weakly reactive

anithals and in two of six non-reactive controls. Twenty $T$. pallidum organisms infected four of five animals, as did 200 organisms; 20,000 organisms infected all five animals having histories of reactive VDRL slide test results. These inocula infected five of six, six of six, and six of six controls, respectively. Rabbits with histories of reactive results with the VDRL slide test, which had not been infected with known treponematoses, were apparently quite susceptible to inoculation syphilis.

\section{Discussión}

Apparently, normal rabbits (those not known to be infected with $T$. pallidum or T. cuniculi) may develop an unexplained transient or sustained overt reagin reactivity, and even occasional reactivity with the FTA-ABS test. With tests other than the TPI, weak or minimal reactivity occurred so often and was so lacking in correlation and reproducibility that consideration here is limited to manifest reactivity (reactive at one dilution, or at $1+$, or greater).

In man, TPI reactivity is taken to indicate present or past treponemal infection. The two TPI-reactive rabbits proved to be infected with cuniculosis and were not included in the findings. Of 1,039 rabbits produced in the south-eastern United States and purchased as adults on the open market, $154(14.8$ per cent.) reacted with the VDRL slide test; and of 486 animals tested, six (1.2 per cent.) reacted with the FTA-ABS test. In the other group of rabbits, from a single strain, bred and maintained in a controlléd laboratory environment and caged individually after 6 weeks of age, 214 (4.9 per cent.) of 4,324 reacted with the VDRL slide test when first examined as young adults; 32 ( 1.3 per cent.) of 2,533 reacted with the FTA-ABS test. The proportion of rabbits from the two sources reactive with the FTA-1:5 test was about the same- 81 ( 16.8 per cent.) of 483 commercial animals and 397 (15.9 per cent.) of 2,504 NCDC animals. With the KRP test, however, the proportion of reactive animals was almost twice as high in the former group; 63 (40.7 per cent.) of 155 tested, as opposed to 98 (20.6 per cent.) of 477 NCDC rabbits.

Reactivity in uninoculated rabbits with the various serological tests has been reported from many parts of the world. T. cuniculosis was diagnosed in a small number of these animals and no doubt was present in some, but by no means all, of the others. It is extremely difficult to exclude the disease with certainty. Even so, most manifest infections would have been noted during routine treponemal research procedures.

Pannu, Rosenberg, Israel, and Smith (1967), examining 149 animals from a commercial rabbitry near Miami, found 10 per cent. to be reactive and 30 per cent. weakly reactive in the VDRL slide test. In a previous report from this laboratory (Mothershed and others, 1967), tests in uninoculated rabbits gave at least weakly reactive results as follows:
FTA-1:5
FTA-ABS
70 of 536 ( 13.0 per cent.);
VDRL slide
0 of 280 ( 0.0 per cent.);

Seven (1.3 per cent.) reacted with both the FTA$1: 5$ and the VDRL tests. Note that in the present larger study, 38 (1.3 per cent.) of 3,019 animals reacted overtly in the FTA-ABS procedure.

The reasons for the bulk of the reactivity and the discrepancies are not yet known. The possibility of technical error cannot be completely excluded. The 


\begin{tabular}{|c|c|c|c|c|c|c|c|c|c|c|c|c|c|c|c|}
\hline \multicolumn{4}{|l|}{5} & \multicolumn{4}{|l|}{6} & \multicolumn{4}{|l|}{7} & \multicolumn{4}{|l|}{8} \\
\hline $\begin{array}{l}F T A- \\
1: 5\end{array}$ & $\begin{array}{l}F T A- \\
A B S\end{array}$ & $\begin{array}{l}\text { VDRL } \\
\text { slide }\end{array}$ & $T P I$ & $\begin{array}{l}\text { FTA- } \\
1: 5\end{array}$ & $\begin{array}{l}F T A- \\
A B S\end{array}$ & $\begin{array}{l}\text { VDRL } \\
\text { slide }\end{array}$ & $T P I$ & $\begin{array}{l}F T A- \\
1: 5\end{array}$ & $\begin{array}{l}F T A- \\
A B S\end{array}$ & $\begin{array}{l}\text { VDRL } \\
\text { slide }\end{array}$ & $T P I$ & $\begin{array}{l}F T A- \\
1: 5\end{array}$ & $\begin{array}{l}F T A- \\
A B S\end{array}$ & $\begin{array}{l}\text { VDRL } \\
\text { slide }\end{array}$ & $T P I$ \\
\hline - & - & $\mathbf{N}$ & - & $\mathrm{N}$ & $\mathbf{N}$ & $\mathbf{N}$ & - & $1+$ & WR & $\mathrm{N}$ & $\mathrm{N}$ & $1+$ & $\mathrm{N}$ & $\mathrm{N}$ & $\dot{N}$ \\
\hline $\mathrm{N}$ & $\mathbf{N}$ & WR & $\mathbf{N}$ & $\mathrm{N}$ & $\mathbf{N}$ & WR & $\mathrm{N}$ & $\mathrm{N}$ & $\mathbf{N}$ & R-1 & $\mathrm{N}$ & WR & $\mathbf{N}$ & R-1 & $\mathbf{N}$ \\
\hline WR & $\mathbf{N}$ & WR & N & $\mathbf{N}$ & $\mathbf{N}$ & $\mathrm{N}$ & $\mathrm{N}$ & $\mathbf{N}$ & $\mathbf{N}$ & $\mathbf{N}$ & - & $\mathbf{N}$ & $\mathbf{N}$ & WR & $\mathbf{N}$ \\
\hline $\mathbf{N}$ & $\mathbf{N}$ & R-1 & $\mathbf{N}$ & $1+$ & $\mathrm{N}$ & WR & $\mathbf{N}$ & $\mathbf{N}$ & $\mathbf{N}$ & $\mathbf{N}$ & $\mathbf{N}$ & WR & $\mathbf{N}$ & $\mathrm{N}$ & $\mathrm{N}$ \\
\hline $1+$ & WR & R-8 & - & $\mathbf{N}$ & $\mathbf{N}$ & $\mathbf{N}$ & - & $1+$ & WR & $\mathbf{N}$ & - & $\mathrm{N}$ & $\mathbf{N}$ & WR & $\mathbf{N}^{i}$ \\
\hline $4+$ & $4+$ & $\mathbf{N}$ & - & $4+$ & $4+$ & $R-4$ & - & $4+$ & $4+$ & $\mathrm{R}-4$ & - & $4+$ & $3+$ & $R-4$ & $\mathbf{N}$ \\
\hline WR & $\mathbf{N}$ & R-1 & - & $2+$ & WR & WR & - & $2+$ & $1+$ & $\mathbf{N}$ & - & $2+$ & $\mathrm{N}$ & $\mathbf{N}$ & - \\
\hline $1+$ & $\mathbf{N}$ & $\mathbf{N}$ & - & $1+$ & $\mathrm{N}$ & $\mathbf{N}$ & - & $2+$ & $\mathbf{N}$ & $\mathbf{N}$ & - & $1+$ & $\mathrm{N}$ & $\mathrm{N}$ & - \\
\hline $3+$ & $1+$ & $R-4$ & - & $2+$ & $\mathbf{N}$ & R-1 & - & WR & $\mathbf{N}$ & WR & $\mathbf{N}$ & WR & $\mathrm{N}$ & R-1 & $\mathrm{N}$ \\
\hline $2+$ & WR & R-1 & - & $3+$ & $1+$ & R-1 & - & $3+$ & $\mathbf{N}$ & R-1 & 一 & $1+$ & $\mathrm{N}$ & $\mathrm{N}$ & $\mathbf{N}$ \\
\hline $2+$ & $\mathbf{N}$ & WR & - & $2+$ & $1+$ & WR & - & $2+$ & $\mathbf{N}$ & $\mathbf{N}$ & - & $1+$ & $\mathrm{N}$ & WR & $\mathbf{N}$ \\
\hline $2+$ & $\mathbf{N}$ & WR & - & WR & WR & WR & $\overline{-}$ & $1+$ & $\mathbf{N}$ & WR & - & $\mathbf{N}$ & $\mathbf{N}$ & $R-1$ & $\mathbf{N}$ \\
\hline WR & $N$ & R-2 & - & $\mathbf{N}$ & $\mathrm{N}$ & WR & $\mathbf{N}$ & WR & WR & R-1 & - & $1+$ & $\mathbf{N}$ & WR & $\mathbf{N}$ \\
\hline $1+$ & $\mathbf{N}$ & N & - & $\mathrm{N}$ & $\mathbf{N}$ & $\mathbf{N}$ & - & $\mathrm{N}$ & $\mathbf{N}$ & $\mathrm{N}$ & - & & $\mathrm{N}$ & $\mathbf{N}$ & $\mathrm{N}$ \\
\hline $1+$ & $\mathbf{N}$ & $\mathbf{N}$ & - & $\mathrm{N}$ & $\mathrm{N}$ & $\mathbf{N}$ & - & $\mathrm{N}$ & $\mathbf{N}$ & $\mathbf{N}$ & - & $2-3 N$ & $\mathbf{N}$ & $\mathrm{N}$ & $\mathbf{N}^{i}$ \\
\hline $1+$ & $\mathbf{N}$ & $R-4$ & - & $2+$ & $\mathrm{N}$ & R-1 & - & WR & $\mathbf{N}$ & R-1 & - & $\mathbf{N}$ & $\mathbf{N}$ & R-1 & $\mathbf{N}$ \\
\hline
\end{tabular}

excellent reproducibility rates of the several serological procedures are not absolute. These factors may be partially responsible for the 1.3 per cent. reactive results to the FTA-ABS test with the initial sera in Table I. However, certain individuals were repeatedly FTA-ABS reactive both with the same specimen and when repeated specimens were collected, as with rabbit No. 3534 in Table IV.

The FTA-ABS procedure which we used with rabbit serum differs from the human test procedure in at least two important respects:

(1) The lack of a reference preparation of reactive rabbit serum for use as a routine positive control;

(2) the lack of a reference preparation of fluorescein-labelled antiserum to rabbit globulin against which to check the performance of routinely used conjugates.

Reactivity in the two types of tests can exist independently. Of the 447 VDRL-reactive rabbits subjected to the FTA-ABS procedure, only 7 per cent. reacted; 25 per cent. of 126 FTA-ABS reactors also reacted with the VDRL slide test

The reactivity of some rabbits appeared to vary with time. Many of these may have been reactive near the threshold levels of the tests, the area in which technical variations are most difficult to control. Of the rabbits initially non-reactive with the respective tests, only 1 per cent. reacted at reportable levels with the VDRL slide test and 2 per cent. with the FTA-ABS, 4 to 8 weeks later (Figure). Of the 56 initially VDRL-reactive animals which were reexamined after 4 to 8 weeks, 86 per cent. remained reactive and another 5 per cent. showed minimal reactivity.

The cumulative effects of these and other factors in repeated examinations over many months are shown in Table III. Detailed serological histories of all sixteen rabbits examined as many as eight times over 12 to 18 months are given in Table IV. This group was followed because of STS reactivity in the first, second, or third examination. Seven of the sixteen, including the one initial reactor, remained constant with the FTA-ABS test. Nine rabbits initially non-reactive showed FTA-ABS reactivity at some time during observation, eight in only one and the other in two, of the eight periodical examinations. Results of 92 per cent. of the 122 FTA-ABS tests with these sixteen rabbits were in agreement with those of their initial tests. In this group, four of the five VDRL non-reactors remained so. The fifth reacted with four of eight tests. Reactivity levels of the ten which were reactive with the VDRL slide test when first examined decreased with time. In late latent syphilis, reagin levels in the rabbit, as in man, tend to decrease. Of eighty animals with syphilis, repeatedly darkfield positive and VDRLreactive in the early stages. and TPI-reactive at 6month intervals thereafter, three ( 3.8 per cent.) reverted to VDRL-non-reactivity 1 year after infection and seven ( 8.8 per cent.) 2 years after infection. In similar rabbits observed for 3,4 , and 5 years, the VDRL slide test became non-reactive in seven of the forty ( 17.5 per cent.), in two of seventeen ( 11.8 per cent.), and in one of nine ( 11.1 per cent.) respectively (Clark, unpublished data).

As far as can be determined, our animals were free of $T$. cuniculi. We think it virtually impossible 
for the 4,324 laboratory-produced rabbits to have been exposed to $T$. cuniculi before delivery. We house rabbits inoculated with different strains of treponemata in separate areas. However, not all experimental procedures produce infection in each subject. Rabbits in cages adjacent to those of infected animals have remained healthy throughout months of observation. We have never had a known inadvertent rabbit-to-rabbit transfer of a treponemal infection, and in our experience $T$. pallidum is rarely, if ever, transmitted by extended intimate rabbit-to-rabbit association (Clark, unpublished data).

Of the tests studied, the VDRL slide and FTAABS tests are the most useful for determining the preinoculation serological status of rabbits to be used for treponemal research. A reactive TPI test as performed in this laboratory with sera from uninoculated rabbits is pathognomonic of cuniculosis. However, the test may be non-reactive after months or years of $T$. cuniculi infection (Clark, in preparation). As yet, no serological test or combination of tests known to us can definitely rule out the presence of cuniculosis. T. cuniculi can be avoided with certainty only by the exclusive use of rabbits from colonies free of the infection, or perhaps by anti-treponemal treatment of all rabbits upon receipt.

Serological status is an important but not infallible criterion of infection with experimental syphilis in rabbits. A trend in reactivity over a period of months is of much greater significance than single test results. An analysis of all available pertinent informtion is sometimes necessary to determine the presence or absence of syphilis in the experimental animal as well as in man.

Reactivity in uninoculated rabbits was reported shortly after serological tests for syphilis were devised (Kolmer and Casselman, 1913). An awareness that this may occur in the absence of known treponemal infection can improve the design and interpretation of syphilis experimentation in the rabbit. Explanation for this reactivity may lead to a better understanding of the pathology and immunology of syphilis. Knowledge of the situation, as revealed by the several tests in large numbers of healthy rabbits from two different backgrounds, may be beneficial. The lack of significance of 'weakly reactive' results in other than the TPI test and the pitfalls inherent in one test on a single specimen are obvious.

\section{Summary}

Upon initial examination of adult rabbits not infected with Treponema cuniculi, 14.8 per cent. of 1,039 animals commercially produced in the southeastern United States reacted at one dilution or more with the Venereal Disease Research Laboratory
(VDRL) slide test, and 1.2 per cent. of 486 animals reacted at $1+$ or greater with the fluorescent treponemal antibody-absorption (FTA-ABS) test. In rabbits raised in a controlled laboratory environment, 4.9 per cent. of 4,324 reacted with the VDRL slide test and 1.3 per cent. of 2,533 with the FTA-ABS test. Of the first group, 16.8 per cent. of 483 reacted overtly (1+ or greater) with the FTA-1 : 5 and 40.7 per cent. of 155 with the Kolmer Reiter protein antigen (KRP) test; of the second group, 15.5 per cent. of 2,504 reacted with the FTA-1 :5 and 20.6 per cent. of 477 with the KRP test.

The Treponema pallidum immobilization test was non-reactive in 2,392 uninfected rabbits. Agreement between the other tests was poor. The results with the same rabbits over a period of time were so inconsistent that, of the four remaining tests, only the VDRL slide and FTA-ABS tests were considered practicable in establishing preinoculation serological base lines for rabbits used in syphilis research.

The author wishes to express appreciation to the staffs of Reagents, Testing, and Evaluation Subunit, and of the Treponematoses and Allied Diseases Research Unit, who performed the serological tests cited, and also to Dr. Leslie C. Norins. Mr. John A. Crawford and Mr. Henry L. Smith are thanked for performing many of the technical tasks.

\section{References}

CLARK, J. W., JR., in preparation.

-, unpublished data.

Kolmer, J. A., and CAsSElman, A. J. (1913). F. med. Res., 28, 369.

Mothershed, S. M., Yobs, A. R., and ClaRK, J. W., JR. (1967). Brit. F. vener. Dis., 43, 267.

PanNu, J. S., Rosenberg, M. A., IsrakL, C. W., and SMITH, J. L. (1967). Ibid., 43, 114.

SMITH, J. L., and PeSETSKy, B. R. (1967). Ibid., 43, 117. U.S. Public Health Service (1964). 'Serological Tests for Syphilis-1964 Manual'. PHS Publication No. 411, U.S. Government Printing Office, Washington, D.C.

Tests sérologiques pour la syphilis chez les lapins sains

SOMMAIRE

Lors de l'examen initial de lapins adultes non infectés par Treponema cuniculi, 14,8 pour cent de 1.039 animaux, fournis par le commerce dans le sud-est des Etats-Unis, furent positifs, à une dilution ou plus, avec le test sur lame du Venereal Disease Research Laboratory (V.D.R.L.) et 1,2 pour cent de $\mathbf{4 8 6}$ animaux furent positifs à $1+$ ou davantage avec le test de l'anticorps tréponémique fluorescent absorbé (FTA-ABS). Chez les lapins élevés 
en milieu de laboratoire contrôlé, 4,9 pour cent de 4.324 animaux réagi snt au V.D.R.L. sur lame, et 1,3 pour cent de 2.533 à l'épreuve FTA-ABS. Dans le premier groupe, 16,8 pour cent de 483 furent nettement positifs ( $1+$ ou davantage) avec le FTA-1:5, et 40,7 pour cent, parmi 155, avec l'épreuve de Kolmer à l'antigène protidique de Reiter (KRP). Dans le second groupe, 15,5 pour cent de 2.504 animaux furent positifs avec le FTA$1: 5$, et 20,6 pour cent de 477 avec l'épreuve KRP.
Le test d'immobilisation du tréponème (TPI) fut négatif chez 2,392 lapins non infectés. L'accord avec les autres épreuves fut mauvais. Les résultats sur toute une période avec les mêmes lapins furent tellement inconsistants que, des quatre autres tests, seul le VDRL sur lame et le FTA-ABS sont considérés comme pratiques pour servir de base à la sérologie précédant l'inoculation, chez les lapins utilisés pour les recherches de syphilis expérimentale. 